\title{
"W biegu..."
}

\author{
Barbara Kanold
}

Gdańsk: Wydawnictwo Oskar, 2015, stron 235

ISBN 978-83-65175-09-0

\section{Wszystko ma swój czas \\ i jest wyznaczona godzina na wszystkie sprawy pod niebem...}

„Księga Koheleta” (Eklezjastesa) [1]
Pod koniec ub. roku ukazała się książka przedstawiająca - w formie obszernego, ponad 200-stronicowego, bogato ilustrowanego wywiadu - wybrane aspekty życia i niektóre z jakże wielu aktywności zawodowych prof. Jacka Jassema. Świadomie nie używam słowa „,biografia”, gdyż jest to raczej luźna rozmowa, swobodnie poruszająca się w latach zarówno odległych, jak i zupełnie współczesnych, oraz wśród wybranych tematów.

Nie jest moją rolą streszczanie jej zawartości - niech przyjemność poznania treści będzie udziałem tych, którzy sięgną po książkę. A zważywszy na pozycję Profesora w środowisku, mało kto - jak sądzę - nie sięgnie. Nie-

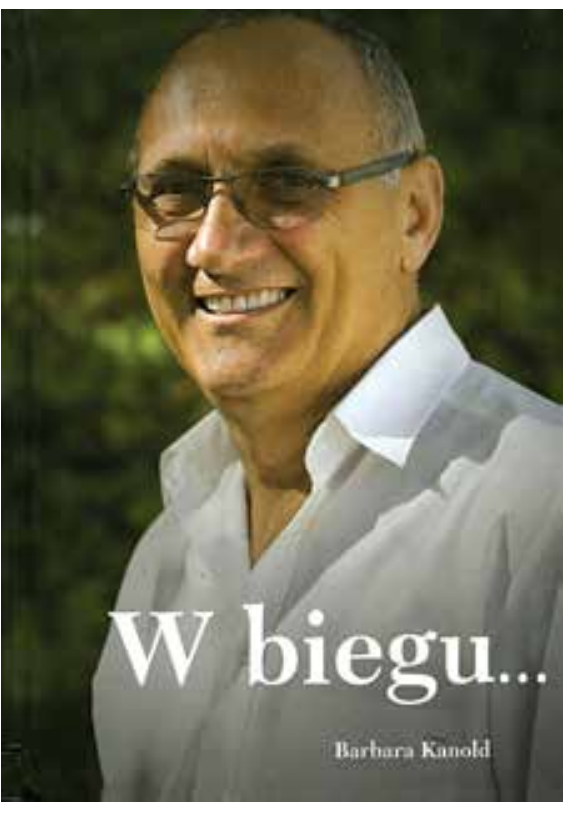

Na kartach przewijają się też nazwiska wielkich postaci współtworzących w różnych okresach onkologię europejską i światową, z którymi Jacek Jassem miał okazję nie tylko spotykać się, ale i owocnie współpracować, jak Jerzy Einhorn, Sandor Eckhardt, Harry Bartelink, Joop van Dongen, Harald zur Hausen. Ta lista mogłaby zresztą być bardzo długa; jak Profesor sam przyznaje, jego bieżąca korespondencja zawodowa z całym światem sięga 200 maili dziennie.

Interlokutorzy autorki, opisując Jacka Jassema, nie szczędzą określeń superlatywnych. On sam jest nieporównanie bardziej krytyczny: „Bywam których bardziej zainteresują szczere relacje o nieznanych powszechnie sprawach rodzinnych, inni szukać będą przede wszystkim opisów bieżących wielokierunkowych działań naukowych i organizacyjno-społecznych. A tych ostatnich nie zabraknie:„W moim życiu dominuje praca naukowa, a od ok. dwudziestu lat także działalność publiczna.W tej sytuacji po prostu nie mogę sobie pozwolić na marnowanie czasu" - mówi bohater książki i jest to per excellence nawiązanie do jakże wymownego jej tytułu. niecierpliwy i zbyt wymagający, czasem zbyt wysoko zawieszam poprzeczkę, a ludziom, którzy nie spełniają moich oczekiwań, zbyt często daję to poznać". Przyznaje też, że jest bezkompromisowym recenzentem, co nie przysparza mu zwolenników, a chorym na raka - w przeciwieństwie do wielu lekarzy - przedstawia informacje o chorobie bez eufemizmów. O licznych zaszczytach i wysokich nagrodach mówi: „Miło mi, że są te nagrody, ale ważniejsze jest to, że nauka jest ciągle moim pożądaniem". 
Szczególnie ujęło mnie przypomnienie o społecznym wymiarze choroby nowotworowej: „Chorzy na nowotwór często czują się poślednią częścią społeczeństwa... Zdarza się, że muszą przerwać naukę lub pracę, pogarsza się ich sytuacja materialna, walą życiowe plany... Dla mnie osoby walczące z chorobą nowotworową są bohaterami...."

Nie mogło zabraknąć wspomnień o niezwykłej pasji-dorocznych wyprawach,survivalowych"w najodleglejsze i najdziksze zakątki świata, w warunkach często ekstremalnych. Pamiętamy pierwszą publiczną relację na ten temat, ilustrowaną znakomitymi zdjęciami, podczas sesji,,humanistycznej"III Kongresu Onkologii Polskiej we Wrocławiu przed czterema laty.

Znając Jacka i współpracując z Nim od dawna przyznaję, że tytuł książki został dobrany niezwykle trafnie. Nawiązuje do niego cytowany na ostatniej stronie fragment dzieła Lewisa Carolla "Pod drugiej stronie lustra" — kontynuacji,_Alicji w krainie czarów". Czerwona Królowa tłumaczy tam Alicji: „Trzeba biec z całą szybkością, na jaką możesz się zdobyć, żeby pozostać w tym samym miejscu. A gdybyś chciała się dostać gdzie indziej, musisz biec przynajmniej dwa razy szybciej...."

Mnie zaś nasuwa się, podobnie jak na początku tej notatki, cytat z biblijnej „Księgi Koheleta”:

Zobaczyłem więc, że nie ma nic lepszego, nad to, że się człowiek cieszy ze swych dzieł, gdyż taki jego udział. Bo któż mu pozwoli widzieć, co się stanie potem? [1]

\section{Edward Towpik}

Warszawski Uniwersytet Medyczny

Centrum Onkologii — Instytut im. Marii Skłodowskiej-Curie

\section{Piśmiennictwo}

1. Księga Koheleta. Cyt. za: Biblia tysiąclecia. Pismo Święte Starego i Nowego Testamentu, (http://biblia.deon.pl/rozdzial.php?id=572). 